Some Unpublished Letters of Lord Chesterfield 




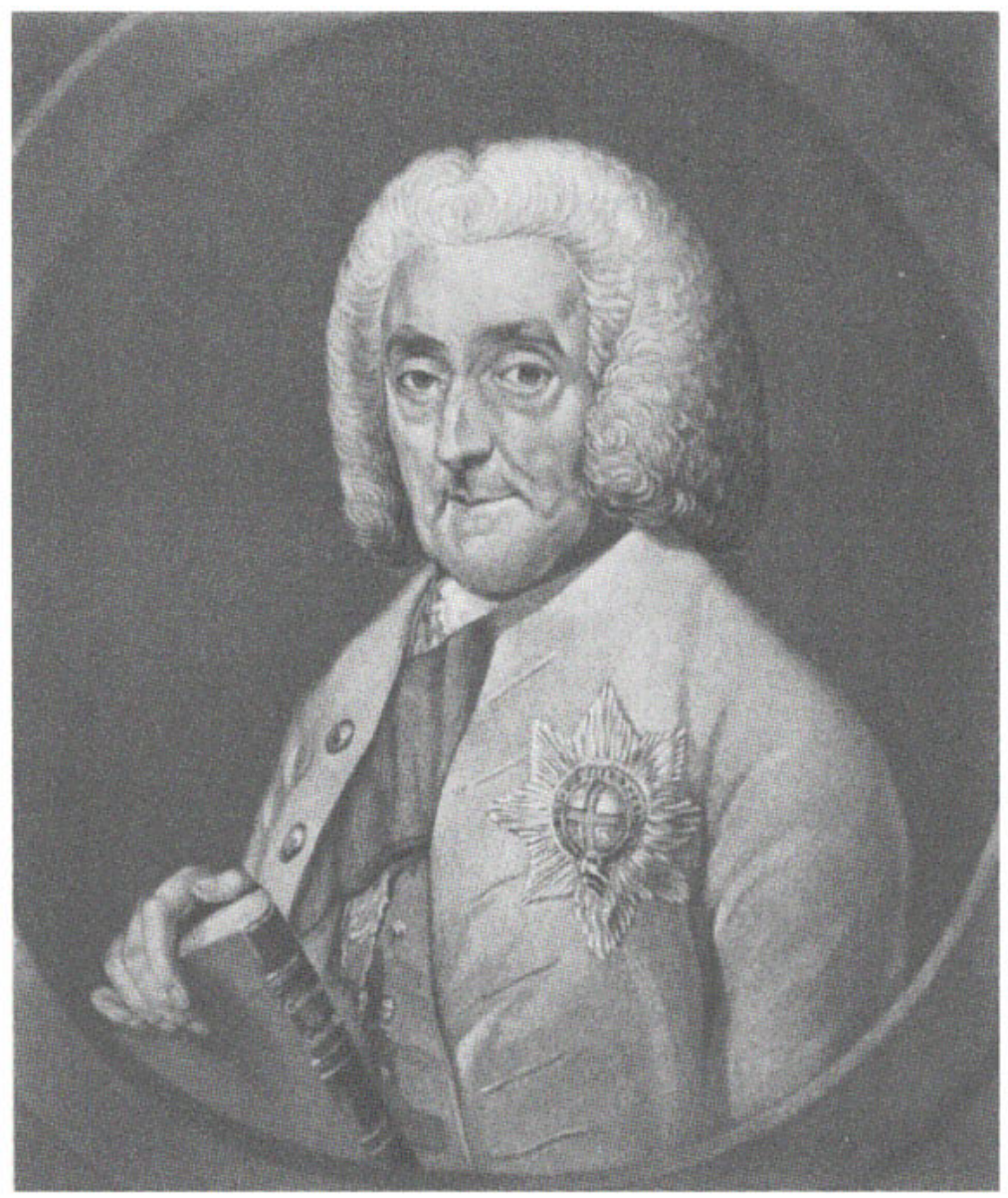

PHILIP DORMER STANHOPE

EARL OF CHESTERFIELD

From an engraving after a painting by Gainsborough 


\section{SOME UNPUBLISHED}

\section{Letters of \\ Lord Chesterfield}

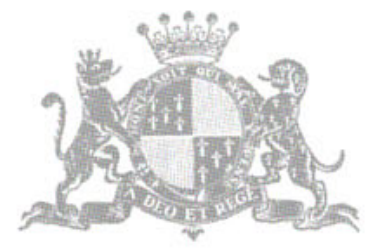

WITH AN INTRODUCTION BY

SIDNEY L. GULIGK, JR.

ASSISTANT PROFESSOR OF ENGLISH

IN MILLS COLLEGE

University of California Press

Berkeley : 1937 


\section{UNIVERSITY OF CALIFORNIA PRESS}

BERKELEY, CALIFORNIA

\section{CAMBRIDGE UNIVERSITY PRESS}

LONDON, ENGLAND

COPYRIGHT, 1937, BY THE

REGENTS OF THE UNIVERSITY OF CALIPORNIA

PRINTED IN THE UNITED STATES OF AMERICA BY SAMUEL T. FARQUHAR, UNIVERSITY PRINTER 


$$
\begin{gathered}
\text { TO MY WIFE } \\
\text { WHOSHARED WITH ME } \\
\text { THE DISCOVERY OF THESE LETTERS }
\end{gathered}
$$


